To cite: SP Tunamsifu 'Twelve years of judicial cooperation between the Democratic Republic of the Congo and the International Criminal Court: Have expectations been met?' (2019) 19 African Human Rights Law Journal 105-125

\title{
Twelve years of judicial cooperation between the Democratic Republic of the Congo and the International Criminal Court: Have expectations been met?
}

\author{
Shirambere Philippe Tunamsifu* \\ Senior Lecturer, Université Libre des Pays des Grands Lacs; Senior Researcher, \\ Centre Africain de Recherche et d' Education à la Paix et à la Démocratie \\ (CAREPD), Democratic Republic of the Congo; Research Fellow, Institute for \\ Dispute Resolution in Africa, University of South Africa \\ https://orcid.org/0000-0001-5381-7944
}

\section{Summary}

The Democratic Republic of the Congo is a party to the Rome Statute. Unable to deal with past serious violations of human rights the country decided formally to refer the situation to the International Criminal Court. Based on article 54(3)(c) of the Rome Statute a judicial cooperation agreement was signed between the DRC and the ICC in 2004. As a result six cases have been prosecuted. The research relied on legislation, literature and empirical fieldwork as its sources of information. To collect data, 29 key informants were interviewed and three focus group discussions were held. After a data analysis the following results were found. Thirteen key informants and participants in the focus group appreciated the ICC's jurisdiction over international crimes and its complementarity to the Congolese judicial system as it brought some relief in the fight against impunity considering the lack of political will on the part of the government to prosecute alleged perpetrators. Eleven key informants and participants in the focus group revealed that the ICC was

LLB (Licence) (Université Libre des Pays des Grands Lacs) MA (University for Peace) LLD/PhD (South Africa); tusphil@yahoo.fr. The article is essentially based on the author's doctoral thesis titled 'A comparative study of transitional justice in the Republic of South Africa and the Democratic Republic of the Congo'. The author's doctoral study received a grant from ULPGL-Goma and the token for thesis writing granted by the Council for the Development of Social Science Research in Africa (CODESRIA) is also acknowledged. 
selective as it prosecuted some perpetrators and freed others (mostly the leaders). Six key informants and participants in the focus group noted that the achievements of the ICC were below the expectations of the population due to the prolonged nature of the proceedings. Six key informants regretted the fact that the ICC does not have retroactive jurisdiction for crimes committed in the DRC before the entry into force of the Rome Statute. Therefore, the study recommends that the ICC should avoid selective justice in prosecuting persons bearing the greatest responsibility. The ICC must also make an effort to prevent further delays in proceedings and avoid long trials in order to meet Congolese expectations and, therefore, restore its credibility and avoid frustration on the part of victims.

Key words: complementarity; crimes; DRC; fight against impunity; International Criminal Court; judicial cooperation; Rome Statute; selective justice; slow proceedings

\section{Introduction}

The Rome Statute establishing the International Criminal Court (ICC) was adopted on 17 July 1998 and entered into force on 1 July 2002 with the determination to put an end to impunity. The ICC is the first permanent and independent criminal court that has the jurisdiction to hold accountable individuals who bear the greatest responsibility for serious international crimes. When states are unwilling or unable to conduct investigations and prosecutions against alleged perpetrators, the ICC appears to be the panacea to fight serious international crimes. The exercise of such jurisdiction, however, is subject to the principle of complementarity ${ }^{1}$ which entails that 'national courts have priority to exercise jurisdiction over the crimes prohibited in the Statute' and, consequently, 'the ICC cannot exercise its jurisdiction over the crimes unless the state concerned is unable or unwilling to investigate or prosecute the crimes'. ${ }^{2}$ As observed by Yang, and rightly so, the principle of complementarity remains one of the remarkable distinguishing features of the ICC in relation to two previous ad hoc international criminal tribunals, as the statutes of the latter clearly accorded them the 'primacy over national courts', 3 which is not the position in the case of the ICC. There are two explanations as to why the principle of complementarity is important. First, the ICC may exercise jurisdiction only where national legal systems fail to do so, including in instances where states purport to

Preamble and art 1 Rome Statute of the International Criminal Court.

$L$ Yang 'On the principle of complementarity in the Rome Statute of the International Criminal Court' (2005) 4 Chinese Journal of International Law 122.

3 See art 9(2) of the Statute of the International Criminal Tribunal for the Former Yugoslavia and art 8 of the Statute of the International Criminal Tribunal for Rwanda. 
act but in reality are unwilling or unable genuinely to carry out investigations or prosecutions. ${ }^{4}$ Heller argues to that effect that 'article 17 permits the Court to find a state "unwilling or unable" only if its legal proceedings are designed to make a defendant more difficult to convict ${ }^{\prime}{ }^{5}$ Second, the principle of complementarity is based both on respect for the primary jurisdiction of states and on considerations of efficiency and effectiveness, since states generally have the best access to evidence and witnesses and the resources to carry out proceedings. 6 Such benefits certainly may have prompted states, including the Democratic Republic of the Congo (DRC), ${ }^{7}$ to ratify the Rome Statute and avail themselves of the opportunity to cooperate with the Court.

In the aftermath of various armed conflicts 8 in which numerous serious crimes were committed, the judiciary in the DRC was unable to deal with the past. 9 Some of the reasons pertain to the fact that 'the different armed conflicts had severely affected the Congolese courts and tribunals, some of which were destroyed, and at that time judges were appointed through irregular processes and based on political considerations'. ${ }^{10}$ There subsequently was a 'total abdication by the state of its own responsibilities'.11 It consequently was not surprising that pursuant to article 13(a) of the Rome Statute, the DRC government on 19 April 2004 decided formally to refer the situation to the ICC for prosecution and to determine whether one or more persons should be charged with crimes under the Court's jurisdiction. ${ }^{12}$

This article aims to examine the extent to which the ICC has met the expectations of victims and survivors of international crimes in the

4 ICC-OTP 'Informal expert paper: The principle of complementarity in practice' (2003) https://www.icc-cpi.int/CR2009_02250.pdf (accessed 22 October 2018).

$5 \mathrm{KJ}$ Heller 'The shadow side of complementarity: The effect of article 17 of the Rome Statute on national due process' (2006) 17 Criminal Law Forum 257. See also MS Ellis 'The International Criminal Court and its implication for domestic law and national capacity building' (2002) 15 Florida Journal of International Law 238.

6 ICC-OTP (n 4).

7 The DRC signed the Rome Statute on 8 September 2000 and deposited its instrument of ratification on 11 April 2002.

8 For a detailed account on armed conflicts in the DRC, see Report of the Mapping Exercise documenting the most serious violations of human rights and international humanitarian law committed within the territory of the Democratic Republic of the Congo between March 1993 and June 2003 (August 2010) https:/ /www.ohchr.org/Documents/Countries/CD/DRC_MAPPING_REPORT_FINAL_EN. pdf (accessed 17 October 2018).

9 Report of the Mapping Exercise (n 8) paras 895-897.

10 SP Tunamsifu 'A comparative study of transitional justice in the Republic of South Africa and the Democratic Republic of the Congo' unpublished LLD thesis, University of South Africa, 2016151.

11 Report of the Mapping Exercise (n 8) para 896.

12 See ICC-OTP 'Prosecutor receives referral of the situation in the Democratic Republic of Congo' ICC-OTP-20040419-50, Press Release, 19 April 2004, http:// www.icccpi.int/en_menus/icc/press\%20and\%20media/press\%20releases/2004/ Pages/prosecutor\%20receives\%20referral\%20of\%20the\%20situation\%20in\%20 the\%20democratic\%20republic\%20of\%20congo.aspx (accessed 12 July 2014). 
DRC, 12 years after it had signed a memorandum of understanding (MoU) to cooperate with the country. Since the signing of the judicial cooperation MoU on 6 October 2004 the ICC has prosecuted four Congolese perpetrators in Ituri and two Rwandan militias in Kivu provinces. This study covers the period between October 2004 and December 2016. It is based on a literature study, legal analysis and empirical field work in areas affected by armed conflict. The study analyses cases prosecuted by the ICC in the situation of the DRC and assesses the expectations of Congolese victims and survivors' 12 years after the signing of the judicial cooperation agreement (2004-2016). The reasons for conducting such a study are two-fold. Because DRC is the first country where the ICC started its investigations, it is relevant to assess the extent to which the Court has met the expectations of victims and survivors. The study also contributes to the existing literature on the ICC by raising the voices of victims and survivors regarding their expectations of the ICC's actions after the crimes committed in the territory of the DRC had been referred to the ICC.

Some data analysed in this study was collected mainly through interviews. In this regard semi-structured and open-ended questionnaires were used in order to obtain key informants' opinions on the ICC's jurisdiction over international crimes, cooperation and its complementarity to national criminal jurisdiction. A purposive sampling strategy was used to elicit information from key informants. Four basic criteria were used to select respondents. The first criterion was based on the participant's role as a representative of the Military High Court (Haute Cour Militaire), while the second was based on the participant's role as representative of the Prosecutor-General of the Republic (Procureur Général de la République). ${ }^{13}$ The third criterion was based on a participant's role as representative of the coordination of civil society organisations in areas affected by armed conflict. The last requirement was that the participant should be a representative of an association of victims of armed conflict or of an association taking care of victims or advocating victims' cases in the courts of law in the DRC. In addition, three focus groups were assembled consisting of survivors' groups and representatives of associations that took care of survivors or advocated victims' cases in courts of law. Twenty-nine indepth interviews were conducted with key informants.

The article is structured in five sections. It begins with an introductory section to the research, followed by an analysis of the legal framework of the judicial cooperation. It then examines the ICC's jurisdiction complementing the Congolese judicial system. Next, perceptions of the Congolese population of the ICC's jurisdiction

13 Art 149(1) of the 2006 Constitution as amended in 2011 provides that '[t]he judicial power is devolved to the courts and tribunals which are the Constitutional Court, the Court of Cassation, the Council of State, the High Military Court, as well as the civil and military courts and tribunals'. The public prosecutor's office falls within their jurisdictions. 
complementing the Congolese judicial system are presented. Lastly, a conclusion and recommendations are presented.

\section{Legal framework of judicial cooperation}

This section discusses the main legal instruments that constitute the basis for judicial cooperation between the DRC and the ICC: first, the Rome Statute establishing the ICC; second, the Judicial Cooperation Agreement between the DRC and the Office of the Prosecutor of the ICC and, lastly, the memorandum of understanding between the United Nations (UN) and the ICC concerning cooperation between the United Nations Organisation Mission in the Democratic Republic of the Congo (MONUC) ${ }^{14}$ and the ICC.

\subsection{Rome Statute establishing the ICC}

In the Preamble to the Rome Statute the parties affirm that measures at the national level should be taken to enhance international cooperation in order for the most serious crimes under the ICC's jurisdiction to be prosecuted and punished. ${ }^{15}$ To achieve the commitment of state parties the Prosecutor in accordance with articles $54(3)(c)$ and (d) must seek the cooperation of any state and conclude arrangements that may facilitate such cooperation. Article 86 stipulates that state parties have the obligation to cooperate fully with the Court in its investigation and prosecution of crimes within its jurisdiction, and article $89(1)$ provides that alleged perpetrators should be arrested and surrendered to the Court.

\subsection{Judicial cooperation agreement between the DRC and the ICC}

With regard to article 54(3)(c) of the Rome Statute the Minister of Justice and the Deputy Prosecutor, on behalf of the DRC and of the ICC, signed the judicial cooperation agreement on 6 October 2004. The purpose of the agreement is to facilitate cooperation and necessary assistance to the ICC's prosecution while conducting investigations and prosecutions within the territory of the DRC (article 1). In this regard the office of the President of the DRC instructed the Auditor-General of the armed forces to cooperate fully with the ICC's investigators in accordance with this agreement. ${ }^{16}$ With respect to the business of the Court, the Court or the team conducting field

14 The United Nations Organisation Mission in the Democratic Republic of the Congo (MONUC), currently the United Nations Organisation Stabilisation Mission in the DRC (MONUSCO).

15 Preamble to the Rome Statute of 17 July 1998, entered in force 1 July 2002, as amended in 2010.

16 Letter from the Office of the President CAB/PR/DC/0699/mac/2005 of 18 June 2005. See M Kabunda 'La coopération entre la CPI et la RDC: A l'épreuve de la pratique' in Avocats Sans Frontières (ASF) Les 10 ans de la Cour Pénale Internationale: Bilan et Perspectives (2012) 74. 
investigations in the DRC must enjoy privileges and immunities necessary to fulfil their purpose (article 48).

\subsection{Memorandum of understanding between the UN and the ICC concerning cooperation between MONUC and the ICC (Relationship Agreement)}

After signature of the peace agreement known as the Global and Inclusive Agreement by governmental officials, representatives of armed militia involved in armed conflicts in the DRC and representatives of civil society organisations in Pretoria, South Africa, on 17 December 2002, the United Nations Security Council (UNSC) through Resolution 1565 committed itself to assist the government of the DRC in the promotion and protection of human rights. ${ }^{17}$ In this Resolution, particular emphasis was placed on support in the investigation of human rights violations in order to bring an end to impunity, and to cooperate with efforts to ensure that perpetrators of serious crimes are brought to justice. ${ }^{18}$ In this regard, the assistance and support provided by paragraphs 1 and 4 to 5 of article 8 of the Relationship Agreement consist of providing aircraft passenger services or transportation in motor vehicles to staff and officials of the Court and to witnesses that are voluntarily cooperating with the Court. Moreover, article 9 provides that the UN Mission may provide military support to the ICC team conducting field investigations where military units are already deployed, and following a request by the ICC Prosecutor, article 10 provides that the team may have access to documents and information held by the UN Mission. According to article 11, the team conducting field investigations may also interview members of the UN Mission where there is good reason to believe that they may have information that cannot be obtained by other means, and may receive testimony by members of the UN Mission as provided for in article 12. In addition, with the written consent of the government of the DRC, article 13 stipulates that the UN Mission may assist the ICC Prosecutor to identify, trace and locate witnesses or victims other than its staff, as well as assist in the preservation of physical evidence for a limited period of time in secure rooms as provided for in article 15. However, according to article 20 it is the responsibility of the Court or the Prosecutor to obtain the prior written consent of the government of the DRC.

17 UNSC Resolution 1565 (2004), para 6(g) http://www.securitycouncilreport.org/ atf/cf/\%7B65BFCF9B-6D27-4E9C-8CD3-CF6E4FF96FF9\%7DDRC\%20SRES1565. pdf (accessed 28 September 2015).

18 UNSC Resolution 1565 (n 17). 


\section{ICC's jurisdiction complementing the Congolese judicial system}

In the aftermath of several internationalised armed conflicts, the judiciary of the DRC was unable (and still is) ${ }^{19}$ to investigate and prosecute widespread gross violations of human rights and serious violations of international humanitarian law committed in the territory of the DRC. Mindful of this state of affairs ${ }^{20}$ in December 2002 delegates to the Inter-Congolese Dialogue ${ }^{21}$ recommended that crimes committed in the DRC since independence (30 June 1960) during different armed conflicts be prosecuted by an ad hoc tribunal that should be created by the UNSC. ${ }^{22}$ The request for the establishment of such a tribunal made by President Joseph Kabila of the DRC before the UN General Assembly in 2003 was not approved due to the high costs involved in both previous ad hoc tribunals of the former Yugoslavia and Rwanda. ${ }^{23}$ As the UN was unwilling to establish the ad hoc tribunal, according to article 13(a) of the Rome

19 In dealing with widespread gross violations of human rights, no state would have adequate resources to deal with the prosecution of hundreds of thousands who have committed widespread crimes during a period of conflict as prosecutions often are expensive, time-consuming and divisive. Tunamsifu (n 10) 1.

20 The different armed conflicts had severely affected the Congolese courts and tribunals, some of which had been destroyed, and at that time judges were appointed through irregular processes and based on political considerations. See Tunamsifu (n 10) 151. Furthermore, 'the number of judges was far below the level needed to handle all the cases that could be referred to the courts'. See UN Doc A/HRC/8/4/Add.2.

21 Following art III19 of the agreement on cease-fire in the DRC signed in Lusaka in July 1999 (Lusaka Agreement), the Inter-Congolese Dialogue - political negotiations on the peace process and on transition - was convened on 25 February 2002 at Sun City, South Africa, after years of internationalised armed conflicts in which foreign armies were involved. Its purpose was to put an end to the conflicts, revive and consolidate a democratisation process and agree on a national reconciliation programme in the DRC. Various elements and entities were involved, such as the government of the DRC; the Congolese Rally for Democracy (RCD); the Movement for the Liberation of the Congo (MLC); the political opposition; civil society; the Congolese Rally for Democracy/Liberation Movement (RDC/ML); the Congolese Rally for Democracy/National (RCD/N); and the MaiMai. After 52 days at Sun City, delegates reached agreement on a cessation of hostilities; the integration of the opposing armed forces; reunification and reconstruction of the country; all-inclusive transitional government in a powersharing, national reconciliation; and so forth. For details, see the Global and Inclusive Agreement on Transition in the DRC: Inter-Congolese Dialogue - Political negotiations on the peace process and on transition in the DRC.

22 See Resolution ICD/CPR/05 relating to the establishment of an International Criminal Court of the Global and Inclusive Agreement on Transition in the DRC.

23 The ICTY and the ICTR have played a crucial role in fighting impunity and have made an important contribution to the development of a rich jurisprudence. However, their annual budgets were rather high given the low number of cases processed. Therefore, the UNSG suggested that 'high priority should be given to consideration of the need to provide for an effective system for delivery of justice'. See Tunamsifu (n 10) 153; UNSC Report of the Secretary-General on the Rule of Law and Transitional Justice in Conflict and Post-Conflict Societies (S/2004/616). 
Statute the DRC decided formally to refer the situation to the ICC on 19 April 2004.24

As stated in the Preamble and article 1 of the Rome Statute, the relationship between the ICC and national criminal jurisdictions is based on the principle of complementarity. However, as provided in article 17, the Court must determine the admissibility of the case if the state which has jurisdiction over it is unwilling or unable to prosecute the person concerned, unless the person has been tried for the conduct in another court where proceedings were conducted independently or impartially. Under the principle of complementarity, Sang-Hyun argues, 'the national judiciary of each state retains the right, and the primary duty, to investigate and prosecute grave violations of international humanitarian law'.25 Thus, the ICC does not replace national jurisdictions, but enables them to prosecute cases in order to ensure sovereignty and takes advantage of the benefits of decentralised prosecution by states closest to the alleged crime and most directly affected by it. ${ }^{26}$ In addition, Fisher argues that '[t]his arrangement aims to ensure that the international authority does no supersede the role of national authorities in the administration of criminal justice'.27 Where national jurisdictions properly can investigate and prosecute offenders, the ICC Prosecutor had assessed that they are normally the most effective and efficient means of bringing offenders to justice since they normally have the best access to evidence and witnesses. 28

In the case of the DRC the ICC complementing the Congolese judicial system remains fundamental because, at the domestic level, national criminal jurisdictions often are unable to adjudicate widespread international crimes due to the lack of means; the highly political and judicial influence that some alleged perpetrators bearing the greatest responsibility might have; the non-progressive reform of the justice sector; insufficient resources; the fragile peace situation; and so forth. In order to avoid the culture of impunity and to fight it in accordance with articles 12(2)(a) and (b), the ICC exercises its jurisdiction over the territorial principle or territorial jurisdiction (ratione loci) and the nationality principle or personal jurisdiction (rationae personae) for war crimes, crimes against humanity, genocide and crimes of aggression, as provided for in article 5.

24 SP Tunamsifu 'Transitional justice and peacebuilding in the Democratic Republic of the Congo' (2015) 65 African Journal on Conflict Resolution 15.1.

25 S Sang-Hyun 'Preventive potential of the International Criminal Court' (2013) 210 Asian Journal of International Law 3.

26 G Werle Principles of international criminal law (2009) 84.

27 KJ Fisher Moral accountability and international criminal law: Holding agents of atrocity accountable to the world (2012) 105.

28 ICC-OTP 'Paper on some policy issues before the Office of the Prosecutor' (2003) http://www.icc-cpi.int/nr/rdonlyres/1fa7c4c6-de5f-42b7-8b25-60aa962ed8b6/14 3594/030905_policy_paper.pdf (accessed 11 July 2014); L Raub 'Positioning hybrid tribunals in international criminal justice' (2009) 1090 International Law Politics 41/1013. 
Twelve years after signature of the judicial cooperation agreement with the DRC under the principle of complementarity the ICC has focused its investigations in the district of Ituri and in both provinces of North and South Kivu where crimes listed in the Rome Statute were perpetrated by Congolese and foreign nationals who were members of armed groups or forces. Two accused were sentenced (Thomas Lubanga and Germain Katanga), while two others were acquitted (Mathieu Ngudjolo and Callixte Mbarushimana). ${ }^{29}$ The trial of one of the accused, Bosco Ntaganda, which commenced in September 2015, closed in August 2018 and the accused is awaiting sentence. ${ }^{30}$ At present one accused, Sylvestre Mudacumura, remains at large. ${ }^{31}$ The cases of Ntaganda and Mudacumura will not be analysed since they have yet to be decided. The study focuses on the cases of Lubanga, Katanga, Ngudjolo and Ntaganda. The analysis consists of presenting both rebel leaders, their armed wings, crimes perpetrated under their leadership and their conviction by the Court.

\subsection{Two cases sentenced: Lubanga and Katanga}

Mr Thomas Lubanga was both the President of a rebel movement named Union des Patriotes Congolais or the Union of Congolese Patriots (UPC) and the commander-in-chief of the armed wing of the ethnic-based UPC called Forces Patriotiques pour la Libération du Congo or Patriotic Forces for the Liberation of Congo (FPLC). Although Lubanga and Katanga were operating in the same areas, the two belonged to different armed groups. Germain Katanga was the former leader of the Front des Nationalistes et Intégrationalistes (FNI) or National Integrationist Front and the commander-in-chief of the Force de Résistance Patriotique en Ituri (FRPI) or Patriotic Resistance Force in Ituri. Crimes they had committed in these areas and the fact that victims were almost the same united the fate of the two former militia men.

The FPLC was allegedly involved in the conscription of children under 15 years of age in order actively to participate in the conflicts and to serve as Lubanga's bodyguards and as ranked military leaders.

29 The Prosecutor $v$ Callixte Mbarushimana [2011] ICC-01/04-01/10-465-Red paras $14-16$ \& 134.

30 'Ntaganda case: The Prosecutor v Bosco Ntaganda ICC-01/04-02/06' 2018 https:// www.icc-cpi.int/drc/ntaganda (accessed 20 October 2018).

31 It is important to note that both Mr Callixte Mbarushimana and Mr Sylvestre Mudacumura are Rwandan nationals alleged to have committed crimes listed in the Rome Statute on the territory of the DRC. Mr Callixte was the Executive Secretary of the Forces Démocratiques pour la Liberation du Rwanda or Democratic Forces for the Liberation of Rwanda (FDLR). The FDLR is a Hutu armed group which over time consisted of Rwandan refugees in the DRC, especially some members of the former Forces Armées Rwandaises or Armed Forces of Rwanda (exFAR) and militias (Interahamwe), implicated in the genocide of 1994 in Rwanda as well as exiled Rwandans seeking political change in Rwanda. Mr Sylvestre was the Supreme Commander of the armed wing of the FDLR during the relevant period. For more, see The Prosecutor $v$ Callixte Mbarushimana (n 29) para 3 and The Prosecutor v Sylvestre Mudacumura [2012] ICC-01/04-01/12-1-Red para 29. 
In addition to this, other crimes such as murder, rape, torture, looting and destruction of property were committed under his leadership. ${ }^{32}$ Such a range of international crimes, although similar as regards victims and effects, differed slightly from those allegedly committed by the FRPI. The FRPI was alleged to have indiscriminately attacked the village of Bogoro and to have conscripted children under the age of 15 years to fight in the conflict. ${ }^{33}$

Lubanga and Katanga were both found guilty by the Court, although on different counts and committed during different periods. On 14 March 2012, pursuant to article 74(2) of the Statute, Lubanga was found guilty as co-perpetrator of the crimes of conscripting and enlisting children under the age of 15 years into the UPC/FPLC and using them to participate actively in conflicts in Ituri. ${ }^{34}$ Katanga was convicted on 7 March 2014 of being an accessory to four counts of war crimes (murder; attacking the civilian population that did not participate in the hostilities; the destruction of enemy property; and pillaging) and one crime against humanity, that of murder, but was not found guilty of the other crimes. ${ }^{35}$ As far as sentence is concerned, on 10 July 2012 Lubanga was sentenced to a total of 14 years' imprisonment ${ }^{36}$ and on 23 May 2014 Katanga was sentenced to a total of 12 years' imprisonment. ${ }^{37}$ On 19 December 2015, in accordance with article 103 of the Rome Statute, Lubanga and Katanga were transferred to Kinshasa to serve the rest of their sentences of imprisonment in Makala Central Prison, ${ }^{38}$ but the time spent in detention at the ICC was deducted from their sentences.

These two cases are worthy of analysis as part of this study for three main reasons. First, they demonstrate a willingness to put an end to impunity instead of leaving crimes committed unpunished. Second, the conviction of perpetrators contributes to the deterrence aimed at preventing international crimes. Third, as a state party the DRC government was the first to refer the situation of crimes committed in its territory to the ICC since 1 July 2002. Under the judicial cooperation agreement Lubanga and Katanga were the first and second rebel leaders brought before the Court for various crimes committed in the armed conflict under their leadership. However, it is unfortunate that the Court did not focus on the ethnic aspect of

32 The Prosecutor $v$ Thomas Lubanga Dyilo [2012] ICC-01/04-01/06-2842 paras 29, $54,65 \& 56$.

33 The Prosecutor $v$ Germain Katanga [2007] ICC-01/04-01/07-1-US-tENG para 5; The Prosecutor v Mathieu Ngudjolo Chui [2007] ICC-01/04-02/07-1-tENG SL PT para 5.

34 The Prosecutor $v$ Thomas Lubanga Dyilo (n 32) paras 1588 \& 1358.

35 The Prosecutor $v$ Germain Katanga [2014] ICC-01/04-01/07-3436 Summary of Trial Chamber II's judgment of 7 March 2014 pursuant to art 74 of the Statute, paras 29-30.

36 The Prosecutor $v$ Thomas Lubanga Dyilo [2012] ICC-01/04-01/06-2901 para 107.

37 The Prosecutor $v$ Germain Katanga [2014] ICC-01/04-01/07-3484 para 170.

38 AFP, https://www.lexpress.fr/actualites/1/monde/cpi-lubanga-et-katanga-transfe res-en-rdcongo-pour-purger-leurs-peines_1747427.html (accessed 11 October 2016). 
conflict but also on the criminal responsibility of foreign military commanders from Rwandan and Ugandan armies involved in the armed conflict. In the Lubanga case it was imperative that the accused be held accountable for other crimes such as murder, rape, torture, looting and destruction of property which were committed under his leadership in the attacks carried out by UPC/FPLC against the Lendu. ${ }^{39}$ In the Katanga case it is unfortunate that the Court acquitted the accused on three counts of war crimes (rape and sexual slavery, and using children under the age of 15 years actively to participate in hostilities) and two crimes against humanity, namely, those of rape and sexual slavery. ${ }^{40}$

\subsection{Two cases acquitted: Ngudjolo and Mbarushimana}

Unlike the previous cases where the two accused were Congolese nationals and crimes were committed in the same area (Ituri), the Ngudjolo and Mbarushimana cases present differences. First, Ngudjolo is a Congolese former rebel leader of the Front des Nationalistes et Intégrationalistes (FNI) or National Integrationist Front commanding the Force de Résistance Patriotique en Ituri (FRPI) or Patriotic Resistance Force in Ituri while Mbarushimana is a Rwandan national and Executive Secretary of the Forces Démocratiques pour la Liberation du Rwanda or Democratic Forces for the Liberation of Rwanda (FDLR), a Rwandan armed group operating in the DRC. Second, Ngudjolo was prosecuted for crimes against humanity and war crimes during the attack on Bogoro on 24 February 2003 while Mbarushimana allegedly committed war crimes and crimes against humanity in the Kivu Provinces in the DRC. ${ }^{41}$ Third, the FNI and FRPI are armed groups consisting of Congolese nationals and led by Ngudjolo, while the FDLR is made up of former members of the Rwandan Armed Forces (ex-FAR) and militias (Interahamwe) who are notoriously known for having committed the 1994 Rwandan genocide. ${ }^{42}$ Lastly, the area of operation also differed since the FNI and FRPI were located in Ituri and FDLR is active in Kivu.

In both cases the prosecution had not proven beyond reasonable doubt that both accused committed the alleged crimes or contributed to those crimes. Therefore, on 17 December 2011 the Court declined by majority to confirm the charges against Mbarushimana, ${ }^{43}$ and on 23 December 2011 he was released from the ICC's custody. ${ }^{44}$

39 The Prosecutor $v$ Thomas Lubanga Dyilo [2012] ICC-01/04-01/06-2879 para 23.

40 Katanga Summary of Trial Chamber II's judgment (n 35) paras 29-30.

41 The Prosecutor $v$ Callixte Mbarushimana (n 29) paras 6 \& 13.

42 The Prosecutor $v$ Callixte Mbarushimana para 3.

43 The Prosecutor $v$ Callixte Mbarushimana paras 14-16 \& 134.

44 As above. 
Ngudjolo was also found not guilty by the Court and was acquitted of all charges against him on 18 December 2012. ${ }^{45}$ On 20 December the office of the Prosecutor appealed the verdict of the Chamber, but the following day he was released from custody. ${ }^{46}$ On 27 February 2015 the Appeals Chamber confirmed the acquittal of Ngudjolo. ${ }^{47}$

Both cases are important for three reasons: First, they reveal much criticism of the method used by the office of the Prosecutor to conduct its field investigations. Second, the Mbarushimana case demonstrates that crimes listed in the Rome Statute perpetrated on the territory of the DRC by nationals of a non-state party will not go unpunished. Third, the silence of the Prosecutor regarding several international crimes committed by Congolese rebel leaders in both North and South Kivu provinces is unfortunate.

In the Ngudjolo case the team of the Prosecutor conducting field investigations failed to prove the charges against him due to security problems as militias were still active in the region. As Bogoro remained unsecured, the Prosecutor could have postponed the trial awaiting the stabilisation of areas where crimes were committed in order to investigate and obtain evidence of those crimes.

The case of Mbarushimana is interesting as the accused is a citizen of Rwanda which is a not a state party to the Rome Statute. Thus, the ICC exercised jurisdiction based on articles 12(2)(a) and (b) of the Statute. In this case, crimes were committed against Congolese civilians in the DRC and the accused was arrested in France (both the DRC and France are state parties). Therefore, regardless of their nationality, the Prosecutor has the duty to prosecute foreigners who bear the greatest responsibility for the crimes committed in the eastern part of the DRC based on the territorial principle. Thus, in order for the office of the Prosecutor to have a good understanding of crimes committed in the Kivu Provinces and elsewhere, this article

45 The Prosecutor v Mathieu Ngudjolo Chui [2012] ICC-01/04-02/12-3-tENG 197. Seven counts of war crimes were brought against Ngudjolo, namely, using children under the age of 15 to take active part in the hostilities; directing an attack against a civilian population as such or against individual civilians not taking part in hostilities; wilful killing; destruction of property; pillaging; sexual slavery; and rape. The three counts of crimes against humanity included murder, rape and sexual slavery. These charges were first confirmed by Pre-Trial Chamber I on 30 September 2008. The Prosecutor v Germain Katanga and Mathieu Ngudjolo Chui [2008] ICC-01/04-01/07 210-212.

46 From the ICC press release it can be read that '[j]udges found that the prosecution had not proved beyond reasonable doubt that Mathieu Ngudjolo Chui was responsible for the crimes committed during the attack. The Office of the Prosecutor has appealed the verdict. The Chamber also ordered the immediate release of Mathieu Ngudjolo Chui following his acquittal. On 20 December 2012, the Appeals Chamber rejected the Office of the Prosecutor's request to keep Mathieu Ngudjolo Chui in custody until the Chamber decides on its appeal of the immediate release decision.' ICC-CPI-20121221-PR868 https://www.icc-cpi.int/ Pages/item.aspx?name=pr868 (accessed 28 May 2018).

47 ICC-CPI-20150227-PR1089 http://www.icc-cpi.int/en_menus/icc/press\%20and\% 20media/press\%20releases/Pages/pr1089.aspx (accessed 25 March 2015). 
strongly encourages its officials to travel to the DRC for field investigations.

\section{Perceptions of the Congolese population regarding the ICC's jurisdiction complementing the Congolese judicial system}

With the help of the interview guide, key informants were asked to reflect on what they thought about the ICC's jurisdiction over international crimes committed in the DRC, the collaboration and complementarity between the ICC and the national system. Responses from participants reveal four major trends: first, that there is complementarity between the ICC and the Congolese judicial system; second, that the ICC undertakes selective prosecutions; third, that the ICC's proceedings are too slow; and, lastly, that there is no retroactivity for crimes committed before the entry into force of the Rome Statute.

\subsection{Complementarity}

Thirteen key informants ${ }^{48}$ and participants in focus group \#1FG ${ }^{49}$ said that the ICC's jurisdiction over international crimes and its complementarity to the Congolese judicial system was well appreciated as it brought some relief in the fight against impunity considering the lack of political will on the part of the DRC government to prosecute alleged perpetrators. For example, key informant \#29 remarked that

the complementarity of the ICC to the Congolese judicial system is significant because it alleviates the immunities and privileges of alleged perpetrators who were promoted in public institutions. Thus, the ICC has annihilated the political weight that can be carried internally.

Key informant \#14 also noted that the intervention of the ICC in the DRC was normal as the DRC is a member state to the Rome Statute. Unfortunately, the DRC government failed to arrest and transfer General Bosco Ntaganda following the fourth ICC arrest warrant against him, arguing that to arrest him would jeopardise peace efforts in the Kivu region. That is why President Kabila invoked the reason of

48 Key informant \#03 interviewed in Bukavu on 20 December 2013; \#06 interviewed in Uvira on 22 December 2013; \#08 interviewed in Kaniola on 23 December 2013; \#10 interviewed in Uvira on 3 January 2014; \#11 interviewed in Bunia on 20 January 2014; \#14 interviewed in Bunia on 21 January 2014; \#16 interviewed in Bunia on 22 January 2014; \#17 interviewed in Bunia on 22 January 2014; \#19 interviewed in Bunia on 24 January 2014; \#20 interviewed in Kisangani on 29 January 2014; \#24 interviewed in Kisangani on 1 February 2014; \#29 interviewed in Kinshasa on 28 March 2014.

49 Focus Group discussion \#1FG held in Bunia on 20 January 2014. 
there being a difficult choice between justice and peace, stability and security in Eastern Congo, his choice was to prioritise peace. 50

However, the population is concerned about the techniques employed by the ICC to conduct field investigations that result in a lack of evidence against alleged perpetrators and, therefore, unconfirmed charges. In order to obtain sufficient evidence, the team of the Prosecutor should ensure that field investigations are conducted where crimes are alleged to have been committed.

Furthermore, key informant \#25 argued that

with only one Prosecutor for all the countries, the ICC will not be able to prosecute all individuals bearing the greatest responsibility in the DRC. Thus, under the principle of complementarity, it is appropriate for Congolese courts that have the first responsibility to commit themselves and prosecute other alleged criminals. ${ }^{5}$

Elements of such a statement were outlined in the letter the ICC Prosecutor sent to President Joseph Kabila on 25 September 2003:52

Since the International Criminal Court will not be in a position to try all the individuals who may have committed crimes under its jurisdiction in Ituri, a consensual division of labour could be an effective approach. We could prosecute some of those individuals who bear the greatest responsibility for the crimes committed, while national authorities, with the assistance of the international community, implement appropriate mechanisms to deal with others. This would send a strong sign of the commitment of the Democratic Republic of the Congo to bring to justice those responsible for these crimes. In return, the international community may take a more resolved stance in the reconstruction of the national judicial and in the reestablishment of the rule of law in the Democratic Republic of the Congo.

Indeed, as stated in the Preamble and article 1 of the Rome Statute, the relationship between the ICC and national criminal jurisdictions is based on the principle of complementarity. Nevertheless, many critics faulted the method used by the office of the Prosecutor to conduct its field investigations. The team conducting the field investigation in Eastern DRC failed due primarily to security problems as militias were still active in the region, gunshots could constantly be heard, and the team could not conduct any investigation outside the city of Bunia which was under the protection of the UN Mission. ${ }^{53}$ Even after Bunia became stable, further field investigations were not conducted.

Findings from the field work further reveal that the ICC's jurisdiction over international crimes and its complementarity to the

50 SP Tunamsifu 'The challenges of the obligation to co-operate between the ICC and the DR Congo: The case of the fourth arrest warrant against General Bosco Ntaganda' (2012) 1 The A38 Journal of International Law.

51 Key informant \#25 interviewed in Kinshasa on 18 February 2014.

52 P Kalume Kambale 'A story of missed opportunities: the role of the International Criminal Court in the Democratic Republic of Congo' in C de Vos, S Kendall \& C Stahn (eds) Contested justice: The politics and practice of International Criminal Court interventions (2015) 177.

53 See C Buisman 'Delegating investigations: Lessons to be learned from the Lubanga judgment' (2013) 34 Northwestern Journal of International Human Rights 11. 
Congolese judicial system reinforce the immunities and privileges enjoyed by alleged perpetrators that had been appointed to public institutions. The findings also corroborate article 1 of the Rome Statute and the views of Song Sang-Hyun that applying the principle of complementarity to the national criminal jurisdictions is fundamental, but does not replace national jurisdictions. Regarding the conduct of the ICC during field investigations, Buisman argues that concern about security in the affected areas was the principal reason for outsourcing the investigation. 54

Thus, the researcher is of the opinion that the ICC's jurisdiction over the cases due to unwillingness to prosecute on the local level is an alternative mechanism in the fight against impunity. However, the investigative failures on the part of the team of the office of the Prosecutor deprive the Court of sufficient evidence, causing victims that expected the alleged perpetrators to be convicted to appear defeated.

\subsection{Selective prosecution}

According to 11 key informants ${ }^{55}$ and participants in focus group $\# 2 \mathrm{FG}^{56}$ the ICC is selective because it prosecuted some perpetrators and freed others (mostly the leaders), and limited its action to crimes committed in Ituri and ignored those committed by domestic armed groups in the Kivu provinces. For example, participants in focus group \#2FG said:

The ICC is selective because it has not prosecuted alleged criminals bearing greatest responsibility who were promoted in the public institutions including former Vice President Azarias Ruberwa, and Rwandan and Ugandan militaries including their respective generals Kabarebe and Kazini.

Similarly, participants in focus group \#3FG believed that ' $[\mathrm{t}]$ he ICC is selective and it has prosecuted on ethnic basis in Ituri, but in Kivu provinces prosecutions are directed against Rwandan rebels while Congolese rebels have not yet been prosecuted as is the case of

54 Buisman (n 53) 3370.

55 Key informant \#03 interviewed in Bukavu on 20 December 2013; \#05 interviewed in Uvira on 21 December 2013; \#06 interviewed in Uvira on 22 December 2013; \#12 interviewed in Bunia on 21 January 2014; \#15 interviewed in Bunia on 22 January 2014; \#18 interviewed in Bunia on 23 January 2014; \#19 interviewed in Bunia on 24 January 2014; \#21 interviewed in Kisangani on 30 January 2014; \#22 interviewed in Kisangani on 31 January 2014l \#27 interviewed in Kinshasa on 6 March 2014; Focus group \#3FG held in Kinshasa on 6 March 2014

Focus Group discussion \#2FG held in Kisangani on 30 January 2014. 


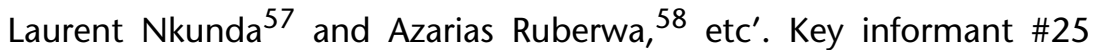
explained:

The ICC's Prosecutor decided to begin investigations in Ituri due to the gravity of the crimes committed there. However, the Congolese courts must be encouraged to prosecute alleged perpetrators because the ICC's Prosecutor will not be able to prosecute all individuals bearing the greatest responsibility of crimes committed in the DRC.

Almost all armed conflicts started in the provinces of North and South Kivu where hundreds of local and foreign armed groups operate (and some still do) that have experienced the most serious crimes of concern to all human kind. Peace agreements signed between warring parties allowed former rebel leaders to be promoted and granted important positions in the government as well as in the army and police forces. As no prosecution has as yet been undertaken against any former rebel leader the armed wing of which is alleged to have perpetrated serious human rights violations as well as gross violations of international humanitarian law, neglecting or delaying prosecution in both Kivu provinces is regarded as selective, on the one hand, and as impunity, on the other. Thus, peace agreements signed to end armed conflicts allowing the integration and promotion of former rebel leaders into public institutions are seen as an umbrella against prosecution at domestic and international levels.

The analysis of the field work reveals that the ICC is selective in its handling of cases because in the DRC it prosecuted some perpetrators and left others (presumably the leaders) untouched and limited its operations to crimes committed in Ituri and not those committed by Congolese warlords in the Kivu provinces.

On that basis, the researcher is of the opinion that findings from the fieldwork in the DRC demonstrate that prosecutions are selective because the ICC focused mainly on Ituri and has not yet carried out serious prosecutions of former Congolese warlords or officials who are now integrated into and promoted within public institutions and are

57 Under Nkundan military leadership, the armed wing of the CNDP is alleged to have committed various crimes in South and North Kivu provinces. In South Kivu these include pillage; the rape of women; mass killings; the destruction of economic infrastructures; and the burning of the Kadutu market in Bukavu. In North Kivu the crimes include an attack on Mugunga internally-displaced persons and mass killings in Kiwanja. See SP Tunamsifu 'International humanitarian law violations in the armed conflict in eastern part of DR Congo: The case of the National Congress for the Defence of People' (2013) 1 The A38 Journal of International Law 247-250.

$58 \mathrm{Mr}$ Azarias Ruberwa is an alleged rebel leader of the former Congolese Rally for Democracy Goma faction (RCD) created on 2 August 1998 backed by Rwanda. Among the crimes listed in the Rome Statute, it is alleged that from mid-july 2002 to the installation of a transitional government in June 2003, various crimes were committed by the former combatants of the RCD-Goma. These include widespread acts of sexual violence for long periods; extra-judicial killings; and widespread looting in Kisangani and in North and South Kivu provinces. See Human Rights Watch 'Seeking justice: The prosecution of sexual violence in the Congo' Vol 17, No 1(A) and Human Rights Watch 'War crimes in Kisangani: The responses of Rwandan-backed rebels to the May 2002 mutiny' Vol 14, No 62002. 
alleged to be perpetrators of crimes committed in the Kivu provinces. However, even in the Ituri district no arrest warrant has been issued for Ugandan and Rwandan soldiers who are alleged to have committed crimes during the internationalised armed conflicts in Ituri. No effort has yet been made at the local level, but the principle of complementarity would work better if the prosecution targeted perpetrators from all sides of the conflicts in provinces affected by conflict.

\subsection{Delay in proceedings}

Six key informants ${ }^{59}$ and participants in focus group \#1FG noted that the achievement of the ICC was below the expectations of the population due to the prolonged nature of the proceedings. For example, participants in focus group \#1FG remarked that '[t]he jurisdiction of the ICC is in order because the DRC is a state party to the Rome Statute, but the population is concerned about the slowness of proceedings and the longer trials'. Key informant \#05 also noted that ' $\mathrm{t}$ ] $\mathrm{he}$ ICC is too slow and this slowness worries victims because since 2002 it has prosecuted very few perpetrators only one of which was convicted; Mr Thomas Lubanga'.

Several authors have criticised the slow pace of ICC proceedings as well as the delay of the Appeals Chamber in issuing judgments. The fact that proceedings often are too slow and the trials prolonged have disappointed victims awaiting the conviction of their persecutors and for reparations. Thus, the ICC must make an effort to prevent further delays in proceedings and avoid long trials in order to restore the credibility of the Court and to avoid frustration on the part of victims. 60

Findings from the fieldwork also reveal that the Congolese population is concerned about the slow pace of proceedings and the prolonged trials. This finding corroborates the observation of a

59 Key informant \#05 interviewed in Uvira on 21 December 2013; \#11 interviewed in Bunia on 20 January 2014; \#12 interviewed in Bunia on 21 January 2014; \#13 interviewed in Bunia on 21 January 2014; \#16 interviewed in Bunia on 22 January 2014; \#26 interviewed in Kinshasa on 21 February 2014.

60 BLE Luzolo \& MNA Bayona Manuel de Procédure Pénale (2011) 759; BM Rowe \& $\checkmark$ Steger 'The International Criminal Court: A case for conservatives' (2014) 8 http://www.amicc.org/docs/A_Case_for_Conservatives_(July_2014).pdf (accessed 20 August 2015); D Mihajlov 'Dr Alina loana Szabó (née Apreotesei): The International Criminal Court: Starting with Africa' (2011) 8 Miskolc Journal of International Law 33; International Bar Association Enhancing efficiency and effectiveness of ICC proceedings: A work in progress (2011) 19; M LabordeBarbanègre \& $R$ Cassehgari 'Reflections on ICC jurisprudence regarding the Democratic Republic of the Congo: Drawing lessons from the Court's first cases' 1 https://www.ictj.org/sites/default/files/ICTJ-Briefing-DRC-ICCReflections-2014.pdf (accessed 15 August 2015); War Crimes Research Office (WCRO) 'Expediting proceedings at the International Criminal Court' 48 50-51 https://www. wcl.american.edu/warcrimes/icc/documents/1106report.pdf (accessed 15 August 2015); Avocats sans Frontières 'Modes of participation and legal representation' 14 http://www.asf.be/wp-content/uploads/2013/11/ASF_IJ_Modes-of-participa tion-and-legal-representation.pdf (accessed 15 August 2015). 
number of authors such as Rowe and Steger, Mihajlov, LabordeBarbanègre and Cassehgari, and of the War Crimes Research Office, confirming the issue of the slow pace of proceedings of the ICC as well as of the Appeals Chamber to issue its judgments.

The researcher is of the opinion that the frustration of the millions of victims (compared to the hundreds of thousands of perpetrators) with the delay in proceedings and trials is understandable. If the ICC does not expedite its proceedings and trials, many victims are likely to have died before a final verdict is reached in their case.

\subsection{Non-retroactivity}

According to six key informants, ${ }^{61}$ the ICC does not have retroactive jurisdiction for crimes committed in the DRC before the entry into force of the Rome Statute. For example, key informant \#19 confirmed that '[t]he Congolese population welcomed the investigation of the ICC, however the population deplores the fact that it will not have retroactive jurisdiction for crimes that were committed before its entry into force in the DRC'.

Article 24 of the Rome Statute provides:

(1) No person shall be criminally responsible under this Statute for conduct prior to the entry into force of the Statute.

(2) In the event of a change in the law applicable to a given case prior to a final judgment, the law more favourable to the person being investigated, prosecuted or convicted shall apply.

The analysis of the fieldwork shows that the population deplores the fact the ICC does not have retroactive jurisdiction for crimes committed in the DRC before the entry into force of its Statute. This finding corresponds with article 24 of the Rome Statute which guarantees the principle of non-retroactivity ratione personae. The principle implies that the ICC has jurisdiction only over crimes committed after the entry into force of the Rome Statute on 1 July 2002.

This research notes that respondents are aware that according to article 24 of the Rome Statute the Court cannot exercise jurisdiction over any crime committed before 1 July 2002. It is suggested that a hybrid tribunal be established that would have jurisdiction over crimes committed before July 2002 in the DRC in which Congolese and nonstate actors from neighbouring countries have been involved.

61 Key informant \#19 interviewed in Bunia on 24 January 2014; \#21 interviewed in Kisangani on 30 January 2014; \#23 interviewed in Kisangani on 30 January 2014; \#24 interviewed in Kisangani on 1 February 2014; \#26 interviewed in Kinshasa on 21 February 2014; \#27 interviewed in Kinshasa on 6 March 2014. 


\section{Conclusion and recommendations}

Serious violations of human rights and of international humanitarian law were committed in the DRC during different phases of internationalised armed conflicts involving state and non-state actors (Congolese and foreign). Affected by the long regime of dictatorship and the various armed conflicts, the judiciary was unable to deal with the large number of perpetrators of crimes related to different armed conflicts.

It is the primary responsibility of the state to investigate and prosecute crimes. However, as the judiciary was already ailing in the aftermath of the various internationalised armed conflicts in which widespread crimes were committed, the situation of crimes committed in the territory of the DRC was referred to the ICC. Under the principle of complementarity the ICC prosecuted a few cases which represented an important breakthrough in the fight against impunity, but it was unable to prosecute the numerous perpetrators that bear the greatest responsibility for the crimes relating to the different armed conflicts. Thus, 12 years since the judicial cooperation agreement was reached the ICC's jurisdiction over international crimes and its complementarity to the Congolese judicial system is appreciated by the population considering the lack of political will on the part of the government to prosecute alleged perpetrators, mainly the former several high-ranking rebel leaders who were integrated into and promoted in public institutions.

However, the ICC has been criticised for prosecuting some perpetrators and freeing others (mostly the leaders), and for the fact that no action has been taken against Ugandan and Rwandan soldiers who allegedly committed serious crimes during the different internationalised armed conflicts. This practice was regarded as selective justice. The ICC's proceedings are believed to be of a prolonged nature with the result that the achievements of the ICC are below the expectations of the population.

The study, therefore, recommends that the ICC should avoid selective justice in prosecuting people bearing the greatest responsibility. The fact that proceedings often are too slow and the trials prolonged have disappointed victims awaiting the conviction of their persecutors and for reparations. Thus, the ICC must make an effort to prevent further delays in proceedings and avoid long trials in order to meet Congolese expectations, restore its credibility, and avoid frustration on the part of victims.

\section{List of participants (key informants and focus groups)}

- $\quad$ Participants in the focus group \#1FG held in Bunia on 20 January 2014. Staff of at Réseau Haki na Amani in Bunia. Gender: F: 3, M: 2

- $\quad$ Participants in the focus group \#2FG held in Kisangani on 30 January 2014. Focus group with the Comité du fond de solidarité des victimes de guerre de six jours à Kisangani. Gender: F: 2, M: 10 
- $\quad$ Participants in the focus Group discussion \#3FG held in Kinshasa on 6 March 2014. Staff of the International Center for the Transitional Justice in Kinshasa. Gender: F: 1, M: 2

- Key informant \#01 interviewed in Goma on 17 December 2013. Staff of Association du Barreau Américain à Goma. Gender: M: 2

- Key informant \#02 interviewed in Goma on 18 December 2013. Member of the Coordination Provinciale de la société civile du Nord Kivu à Goma. Gender: M: 1

- Key informant \#03 interviewed in Bukavu on 20 December 2013. Person at Hôpital Général de Panzi à Bukavu. Gender: M: 1

- Key informant \#04 interviewed in Bukavu on 20 December 2013. Member of the Coordination Provinciale de la société civile du SudKivu. Gender: M: 1

- Key informant \#05 interviewed in Uvira on 21 December 2013. Staff of Genre actif pour un devenir meilleur de la femme (GAD) in Uvira. Gender: F: 1

- Key informant \#06 interviewed in Uvira on 22 December 2013. Staff of the entity Village de Makobola in Uvira. Gender: M: 1

- $\quad$ Key informant \#07 interviewed in Kaniola on 23 December 2013. Staff of the Paroisse Reine de tous les Saints de Kaniola à Bukavu. Gender: M: 1

- Key informant \#08 interviewed in Kaniola on 23 December 2013. Staff of the Bureau d'écoute Justice et Paix at the Paroisse Reine de tous les Saints de Kaniola in Bukavu. Gender: F: 1

- $\quad$ Key informant \#09 interviewed in Burhale on 23 December 2013. Staff of the Paroisse Saint Jean Apôtre de Burhale à Bukavu. Gender: M: 1

- $\quad$ Key informant \#10 interviewed in Uvira on 3 January 2014. Staff of the Cadre de Concertation inter-ethnique de Uvira. Gender: M: 1

- Key informant \#11 interviewed in Bunia on 20 January 2014. Staff of Caritas Bunia. Gender: M: 1

- $\quad$ Key informant \#12 interviewed in Bunia on 21 January 2014. Staff of Association des Mamans Anti Bwaki de Bunia and former Commissioner of the Commission Vérité et Réconciliation in the DRC. Gender: F: 1

- $\quad$ Key informant \#13 interviewed in Bunia on 21 January 2014. Staff of Ecole de la Paix des Missionnaires d'Afrique in Bunia. Gender: M: 1

- $\quad$ Key informant \#14 interviewed in Bunia on 21 January 2014. Staff of Coopération Internationale in Bunia. Gender: M: 1

- Key informant \#15 interviewed in Bunia on 22 January 2014. Staff of the Centre de recherche de I'Institut Supérieur Pédagogique de Bunia. Gender: M: 1

- Key informant \#16 interviewed in Bunia on 22 January 2014. Staff of Justice Plus in Bunia. Gender: M: 1

- Key informant \#17 interviewed in Bunia on 22 January 2014. Representative of the Hima community of Bunia. Gender: M: 1

- Key informant \#18 interviewed in Bunia on 23 January 2014. Member of the Coordination de la Société civile de Bunia. Gender: M: 1

- $\quad$ Key informant \#19 interviewed in Bunia on 24 January 2014. Person representing Lendu community of Bunia. Gender: M: 1

- $\quad$ Key informant \#20 interviewed in Kisangani on 29 January 2014. Staff of Congo en Images in Kisangani. Gender: M: 1

- $\quad$ Key informant \#21 interviewed in Kisangani on 30 January 2014. Staff of Actions et Réalisations pour le Développement de Kisangani. Gender: M: 1

- $\quad$ Key informant \#22 interviewed in Kisangani on 31 January 2014. Member of the Coordination Provinciale de la société civile de Kisangani. Gender: M: 1 
- Key informant \#23 interviewed in Kisangani on 30 January 2014. Staff of the Commission Justice et Paix de la Province Orientale. Gender: M: 1

- $\quad$ Key informant \#24 interviewed in Kisangani on 1 February 2014. Staff of Union pour le développement de la Province Orientale. Gender: M: 1

- Key informant \#25 interviewed in Kinshasa on 18 February 2014. Staff of the Bureau de la représentation de la CPI à Kinshasa. Gender: M: 1

- $\quad$ Key informant \#26 interviewed in Kinshasa on 21 February 2014. Staff of Coalition pour la CPI à Kinshasa. Gender: M: 1

- $\quad$ Key informant \#27 interviewed in Kinshasa on 6 March 2014. Member of la Nouvelle Société civile Congolaise à Kinshasa. Gender: M: 1

- $\quad$ Key informants \#28 interviewed in Kinshasa on 25 March 2014. Staff of the Parquet Général de la République in Kinshasa. Gender: M: 1

- $\quad$ Key informants \#29 interviewed in Kinshasa on 28 March 2014. Staff of Haute Cour Militaire à Kinshasa. Gender: M: 1 